\title{
Laboratory Diagnosis of Bacterial Meningitis in a Patient with COVID-19
}

\section{Irena Ivanova Gencheva-Angelova}

Medical University, Pleven, Bulgaria

Email: gencheva1677@gmail.com

How to cite this paper: Gencheva-Angelova I.I. (2021) Laboratory Diagnosis of Bacterial Meningitis in a Patient with COVID-19. Journal of Biosciences and Medicines, 9, 110-115.

https://doi.org/10.4236/jbm.2021.94008

Received: March 17, 2021

Accepted: April 17, 2021

Published: April 20, 2021

Copyright $\odot 2021$ by author(s) and Scientific Research Publishing Inc. This work is licensed under the Creative Commons Attribution International License (CC BY 4.0).

http://creativecommons.org/licenses/by/4.0/

\begin{abstract}
Against the background of a COVID-19 infection, the overlap of bacterial coinfection is associated with an increased risk of poor treatment outcomes. A 76-year-old man was treated for ischemic stroke in the period of one week. During his hospital stay, he showed symptoms of a viral infection, due to which a PCR sample was taken for SARS-CoV-2. The test result was positive. Meningoencephalitis is suspected on the basis of the clinical symptoms shown and the initial blood test. $K$. pneumonia was detected by a cerebrospinal fluid (CSF) microbiological examination. The risk of bacterial coinfection with COVID-19 remains unclear. Timely and rapid diagnosis and treatment of bacterial meningitis, in the context of a proven COVID-19 infection, require a variety of biological tests and a multidisciplinary approach. In the early stages of acute bacterial and viral meningitis, the signs and symptoms are often nonspecific and it is not always possible to make a differential diagnosis. Laboratory tests, characterizing COVID-19, should determine the type, prognosis, and outcome of a bacterial coinfection. Refining the laboratory diagnosis of a bacterial infection with COVID-19 is a new challenge for doctors.
\end{abstract}

\section{Keywords}

Meningitis, Laboratory, Prognosis, CSF, COVID-19

\section{Introduction}

With the spread of the COVID-19 pandemic, reports of bacterial coinfection in sick patients have become more frequent. Its manifestation can be considered as a direct impact of the virus on target organs and systems in humans. There have been reports of some patients developing meningitis due to various bacteria, such as $N$. meningitides [1] [2] [3]. Diagnosing and treating patients with a highly contagious infection, such as COVID-19, is not easy [4] [5]. 
The differential diagnosis of bacterial and viral meningitis remains an important and unsolved clinical problem, especially in the initial hours of hospitalization, before receiving lumbal puncture results. Classical clinical diagnostic signs have limited value in establishing the diagnosis of meningitis [6] [7] [8].

\section{Clinical Case}

A 76-year-old man was treated for ischemic stroke for one week. During his hospital stay, he showed symptoms of a viral infection, due to which a PCR sample was taken for SARS-CoV-2. The test result was positive.

The patient was transferred to the intensive care unit due to a severely deteriorating general condition. He was disoriented and insufficient for time and place.

Physical status: lung-weakened vesicular respiration and wheezing. Heartrhythmic heart activity, 90 beats/minute, clear tones, no noise. Blood pressure $135 / 85 \mathrm{~mm} / \mathrm{Hg}$. The patient is afebrile, with a dry and uncoated tongue. The abdomen is soft, at the level of the chest, respiratory mobile. Liver and spleen are of normal size. Limbs-no swelling.

Neurological status-meningoradicular syndrome. Neck rigidity (+), enhanced tendon supraosseous reflexes; Babinski $(+)$ bilaterally. Cranial nervesvisibly intact.

Computed tomography (CT) of the lung-bilaterally diffuse in the lung parenchyma and subpleural in places are scanned areas looking like "frosted glass". Bilateral subpleural pneumofibrosis.

\section{Results}

The patient was monitored by laboratory tests daily, as shown in Table 1 and Table 2.

Based on the clinical indications and the initial blood test, meningoencephalitis was suspected and a treatment with intravenous antibiotics was started after sending cerebrospinal fluid (CSF) for analysis. CSF analysis (Table 3) showed the presence of elevated leukocytes and erythrocytes, elevated protein and glucose. K. pneumonia was detected by CSF microbiological examination.

Table 1. Mean values and standard deviation of biochemical parameters.

\begin{tabular}{cccc}
\hline Parameter & Average & SD & Ref. range \\
\hline Troponin T & $0.018 \mathrm{ng} / \mathrm{ml}$ & 0.007 & $<0.014 \mathrm{ng} / \mathrm{ml}$ \\
ASAT & $22.5 \mathrm{U} / 1$ & 4.9 & $<40 \mathrm{U} / 1$ \\
ALAT & $23 \mathrm{U} / 1$ & 8.5 & $<40 \mathrm{U} / 1$ \\
CK & $129 \mathrm{U} / 1$ & 80.5 & $<190 \mathrm{U} / 1$ \\
CK- MB & $33.3 \mathrm{U} / 1$ & 17.9 & $<24 \mathrm{U} / 1$ \\
TP & $72.5 \mathrm{~g} / 1$ & 2.1 & $66-87 \mathrm{~g} / 1$ \\
\hline
\end{tabular}




\section{Continued}

\begin{tabular}{|c|c|c|c|}
\hline Alb & $35 \mathrm{~g} / \mathrm{l}$ & 0 & $35-52 \mathrm{~g} / 1$ \\
\hline Glu & $21.8 \mathrm{mmol} / 1$ & 6.6 & $4.11-6.1 \mathrm{mmol} / \mathrm{l}$ \\
\hline Crea & $573 \mu \mathrm{mol} / 1$ & 63 & $53-115 \mu \mathrm{mol} / \mathrm{l}$ \\
\hline Urea & $40.3 \mathrm{mmol} / 1$ & 4.9 & $2.8-8.1 \mathrm{mmol} / \mathrm{l}$ \\
\hline LDH & $822.3 \mathrm{U} / 1$ & 33.5 & $240-480 \mathrm{U} / 1$ \\
\hline CRP & $49 \mathrm{mg} / 1$ & 33.9 & $<5 \mathrm{mg} / \mathrm{l}$ \\
\hline $\mathrm{Na}$ & $148.5 \mathrm{mmol} / \mathrm{l}$ & 3.4 & $135-155 \mathrm{mmol} / \mathrm{l}$ \\
\hline K & $5.65 \mathrm{mmol} / \mathrm{l}$ & 0.4 & $3.5-5.5 \mathrm{mmol} / \mathrm{l}$ \\
\hline $\mathrm{Cl}$ & $118 \mathrm{mmol} / \mathrm{l}$ & 2.8 & $98-108 \mathrm{mmol} / \mathrm{l}$ \\
\hline INR & 8.3 & 1.1 & $0.9-1.2$ \\
\hline Fibrinogen & $2.3 \mathrm{~g} / 1$ & 1.15 & $1.5-4.0 \mathrm{~g} / 1$ \\
\hline D-dimer & $9.86 \mu \mathrm{g} / \mathrm{ml}$ & 2.17 & $<0.5 \mu \mathrm{g} / \mathrm{ml}$ \\
\hline TPUC (CSF) & $1.29 \mathrm{~g} / 1$ & - & $0.15-0.45 \mathrm{~g} / \mathrm{l}$ \\
\hline GLU (CSF) & $16.4 \mathrm{mmol} / \mathrm{l}$ & - & $2.22-4.44 \mathrm{mmol} / \mathrm{l}$ \\
\hline
\end{tabular}

Table 2. Mean values and standard deviation of hematological parameters.

\begin{tabular}{cccc}
\hline Parameter & Average & SD & Ref. range \\
\hline RBC & $4.23 \times 10^{12} / 1$ & 0.32 & $3.7-5.9 \times 10^{12} / 1$ \\
HB & $128 \mathrm{~g} / 1$ & 9 & $120-180 \mathrm{~g} / 1$ \\
MCV & $86 \mathrm{fl}$ & 4 & $82-96 \mathrm{fl}$ \\
HCT & $0.371 / 1$ & 0.02 & $0.36-0.531 / 1$ \\
WBC & $20 \times 10^{9} / 1$ & 12 & $3.5-10.5 \times 10^{9} / 1$ \\
NEU & $92.6 \%$ & 1.15 & $40 \%-83 \%$ \\
MO & $2 \%$ & 0 & $1 \%-11 \%$ \\
LY & $5.3 \%$ & 1.15 & $20 \%-48 \%$ \\
PLT & $162 \times 10^{9} / 1$ & 37.9 & $130-360 \times 10^{9} / 1$ \\
\hline
\end{tabular}

Table 3. Values of the measured parameters in cerebrospinal fluid.

\begin{tabular}{cc}
\hline Parameter & Result \\
RBC & 2869 cells $/ \mu \mathrm{L}$ \\
WBC & 62 cells $/ \mu \mathrm{L}$ \\
MN & $12.2 \%$ \\
PMN & $87.8 \%$ \\
NEU & $87.8 \%$ \\
LYM & $8.1 \%$ \\
MON & $4.1 \%$ \\
\hline
\end{tabular}


The patient is in a very severe general condition-coma with pronounced meningo-radicular syndrome, narrow pupils with a slow reaction to light, evenly weakened vesicular respiration, with bilateral crepitations, haemodynamically stable. In the following days his condition was unchanged, afebrile with good diuresis. Due to blood sugar levels rising, he was consulted with an endocrinologist.

\section{Discussion}

Timely and rapid diagnosis and treatment of bacterial meningitis in the view of a proven COVID-19 infection require a variety of biological tests and a multidisciplinary approach. In the early stages of acute bacterial and viral meningitis, the signs and symptoms are often nonspecific and it is not always possible to make a differential diagnosis.

The gold standard for diagnosing meningitis is a cerebrospinal fluid (CSF) test. It usually lists the blood cells and determines which cells in the white blood cell line dominate.

In our patient it is seen that the number of leukocytes and erythrocytes is increased, respectively: RBC 2869 cells $/ \mu \mathrm{L}$ and WBC 62 cells $/ \mu \mathrm{L}$. As a percentage of white blood cells, neutrophils dominate $-87.8 \%$. These results correlate with the type and severity of the infectious process. The high number of erythrocytes in CSF is an indication of a violation of the blood-brain barrier, which can also occur in SARS-CoV-2 and is associated with cytokine storm syndrome.

In the biochemical tests, protein and glucose are most often determined in cerebrospinal fluid. CSF glucose corresponds to a large proportion of circulating glucose in the blood. The best way to measure a patient's glucose is to establish a link between cerebrospinal fluid glucose and serum glucose.

In this case, it can be seen that our patient had high blood glucose, consequently the glucose in the cerebrospinal fluid was also high $-16.4 \mathrm{mmol} / \mathrm{l}$, despite that in bacterial meningitis the glucose level is typically low, (ref. range in CSF, 2.22 - $4.44 \mathrm{mmol} / \mathrm{l})$.

Regarding the total protein in the cerebrospinal fluid, it is also high $-1.29 \mathrm{~g} / \mathrm{l}$, at a rate of up to $0.45 \mathrm{~g} / \mathrm{l}$. The concentration of protein is directly related to the degree of the infectious process, thus changing the concentration in the CSF. About $80 \%$ of the proteins contained in the cerebrospinal fluid are derived from plasma. The increase in protein is not very specific, but is of great importance for the diagnosis. A high level of total protein is usually equivalent to the degree of pleocytosis [9] [10].

Regarding the biochemical markers used in the diagnosis of meningitis, it can be seen that the patient has elevated CRP, mean value is $49 \mathrm{mg} / \mathrm{l}$ with $\mathrm{SD}=33.9$. Usually this indicator is very useful for the diagnosis and distinguishing viral and bacterial meningitis. Some authors assume that in bacterial meningitis, CRP levels are greater than $85 \mathrm{mg} / \mathrm{l}$ [11]. However, the very high levels of D-dimer, INR and LDH came to the fore in this patient. During the entire stay in the hospital the patient's D-dimer was extremely high-mean value is $9.86 \mu \mathrm{g} / \mathrm{ml}$ (ref 
range $<0.5 \mu \mathrm{g} / \mathrm{ml}$ ) with SD 2.17. In addition, his prothrombin time was significantly prolonged and the mean INR was 8.3 (ref. range $0.9-1.2$ ). The elevated values of $\mathrm{LDH}$ mean $-822.3 \mathrm{U} / \mathrm{l}, \mathrm{SD}=33.5$ correlate with this laboratory finding (Table 1). These laboratory parameters are more typically used in the diagnosis and follow-up of patients with COVID-19. In this regard, elevated levels of D-dimer, fibrinogen and INR are common in patients with severe COVID-19 infection [12] [13] [14].

Studies show that elevated levels of D-dimer particularly in these patients are closely associated with poor prognosis. Anticoagulant therapy can effectively reduce mortality in patients with D-dimer levels above $3.0 \mu \mathrm{g} / \mathrm{ml}$. In addition, patients with an ischemic stroke and elevated D-dimer levels tend to have a worse prognosis against the background of a present severe COVID-19 infection. The exact mechanisms by which COVID-19 induces hypercoagulability in patients remain unclear [15].

\section{Conclusion}

In conclusion, we can say that accurate and rapid diagnosis is not always possible in the context of an infection with COVID-19. Elevated values of D-dimer, fibrinogen, and INR are specific for patients with COVID-19. These parameters could facilitate the early diagnosis. However, there are also a number of factors that complicate this process. They root mainly in the lack of clarity about the pathophysiological mechanisms by which SARS-CoA-2 acts. It is important that patients with COVID-19 are evaluated for neurological changes as early as possible. Moreover, timely laboratory testing and diagnostic imaging of patients with suspected stroke should be performed. Consequently, a multidisciplinary approach is particularly crucial for these patients.

\section{Conflicts of Interest}

The author declares no conflicts of interest regarding the publication of this paper.

\section{References}

[1] Gallacher, S.D. and Seaton, A. (2020) Meningococcal Meningitis and COVID-19 Co-Infection. BMJ Case Reports, 13, e237366. https://doi.org/10.1136/bcr-2020-237366

[2] Moriguchi, T., Harii, N., Goto, J., Harada, D., Sugawara, H., Takamino, J., et al. (2020) A First Case of Meningitis/Encephalitis Associated with SARS-Coronavirus-2. International Journal of Infectious Diseases, 94, 55-58. https://doi.org/10.1016/j.ijid.2020.03.062

[3] Duong, L., Xu, P. and Liu, A. (2020) Meningoencephalitis without Respiratory Failure in a Young Female Patient with COVID-19 Infection in Downtown Los Angeles, Early April 2020. Brain, Behavior, and Immunity, 87, 33. https://doi.org/10.1016/j.bbi.2020.04.024

[4] Mirzaei, R., Goodarzi, P., Asadi, M., Soltani, A., Aljanabi, H.A.A., Jeda, A.S., et al. 
(2020) Bacterial Co-Infections with SARS-CoV-2. IUBMB Life, 72, 2097-2111. https://doi.org/10.1002/iub.2356

[5] Lansbury, L., Lim, B., Baskaran, V. and Lim, W.S. (2020) Co-Infections in People with COVID-19: A Systematic Review and Meta-Analysis. Journal of Infection, 82, 266-275. https://doi.org/10.1016/j.jinf.2020.05.046

[6] Baig, A.M., Khaleeq, A., Ali, U. and Syeda, H. (2020) Evidence of the COVID-19 Virus Targeting the CNS: Tissue Distribution, Host-Virus Interaction, and Proposed Neurotropic Mechanisms. ACS Chemical Neuroscience, 11, 995-998. https://doi.org/10.1021/acschemneuro.0c00122

[7] Rawson, T.M., Moore, L.S.P., Zhu, N., et al. (2020) Bacterial and Fungal Co-Infection in Individuals with Coronavirus: A Rapid Review to Support COVID-19 Antimicrobial Prescribing. Clinical Infectious Diseases, 71, 2459-2468.

https://doi.org/10.1093/cid/ciaa530

[8] Arcari, G., Raponi, G., Sacco, F., Bibbolino, G., Di Lella, F.M., Alessandri, F., et al. (2021) Klebsiella pneumoniae Infections in COVID-19 Patients: A 2-Month Retrospective Analysis in an Italian Hospital. International Journal of Antimicrobial Agents, 57, 106245. https://doi.org/10.1016/j.ijantimicag.2020.106245

[9] Huang, Y.H., Jiang, D. and Huang, J.T. (2020) SARS-CoV-2 Detected in Cerebrospinal Fluid by PCR in a Case of COVID-19 Encephalitis. Brain, Behavior, and Immunity, 87, 149. https://doi.org/10.1016/j.bbi.2020.05.012

[10] De Almeida, S.M., Furlan, S.M.P., Cretella, A.M.M., Lapinski, B., Nogueira, K., Cogo, L.L., et al. (2020) Comparison of Cerebrospinal Fluid Biomarkers for Differential Diagnosis of Acute Bacterial and Viral Meningitis with Atypical Cerebrospinal Fluid Characteristics. Medical Principles and Practice, 29, 244-254. https://doi.org/10.1159/000501925

[11] Gowin, E., Błaszczynski, J., Słowinski, R., Wysocki, J. and Januszkiewicz-Lewandowska, D. (2019) Differential Diagnosis of Bacterial and Viral Meningitis Using Dominance-Based Rough Set Approach. In: Marcos, M., et al., Eds., Artificial Intelligence in Medicine: Knowledge Representation and Transparent and Explainable Systems, Springer, Cham, 29-38. https://doi.org/10.1007/978-3-030-37446-4_3

[12] Wang, C., Horby, P.W., Hayden, F.G. and Gao, G.F. (2020) A Novel Coronavirus Outbreak of Global Health Concern. The Lancet, 395, 470-473.

https://doi.org/10.1016/S0140-6736(20)30185-9

[13] Ahmed, M.U., Hanif, M., Ali, M.J., Haider, M.A., Kherani, D., Memon, G.M., et al. (2020) Neurological Manifestations of COVID-19 (SARS-CoV-2): A Review. Frontiers in Neurology, 11, 518. https://doi.org/10.3389/fneur.2020.00518

[14] Packwood, R., Galletta, G. and Tennyson, J. (2020) An Unusual Case Report of COVID-19 Presenting with Meningitis Symptoms and Shingles. Clinical Practice and Cases in Emergency Medicine, 4, 316-320. https://doi.org/10.5811/cpcem.2020.4.47557

[15] Zhang, S., Zhang, J., Wang, C., Chen, X., Zhao, X., Jing, H., Liu, H., Li, Z., Wang, L., Shi, J., Shi, J., et al. (2021) COVID-19 and Ischemic Stroke: Mechanisms of Hypercoagulability (Review). International Journal of Molecular Medicine, 47, Article No. 21. https://doi.org/10.3892/ijmm.2021.4854 